\title{
Hydroxycarboxylic acid receptors (version 2019.4) in the IUPHAR/BPS Guide to Pharmacology Database
}

\author{
Steven L. Colletti ${ }^{1}$, Adriaan P. IJzerman ${ }^{2}$, Timothy W. Lovenberg ${ }^{3}$, Stefan Offermanns ${ }^{4}$, Graeme Semple $^{5}$, M. \\ Gerard Waters $^{1}$ and Alan Wise ${ }^{6}$ \\ 1. Merck Research Laboratories, USA \\ 2. Leiden University, The Netherlands \\ 3. Janssen Research \& Development, USA \\ 4. Goethe-University Frankfurt, Germany \\ 5. Beacon Discovery Inc, USA \\ 6. GlaxoSmithKline, UK
}

\begin{abstract}
The hydroxycarboxylic acid family of receptors (ENSFM00500000271913, nomenclature as agreed by the NCIUPHAR Subcommittee on Hydroxycarboxylic acid receptors 32,10$]$ ) respond to organic acids, including the endogenous hydroxy carboxylic acids 3-hydroxy butyric acid and L-lactic acid, as well as the lipid lowering agents nicotinic acid (niacin), acipimox and acifran [47, 54, 57]. These receptors were provisionally described as nicotinic acid receptors, although nicotinic acid shows submicromolar potency at $\mathrm{HCA}_{2}$ receptors only and is unlikely to be the natural ligand $[54,57]$.
\end{abstract}

\section{Contents}

This is a citation summary for Hydroxycarboxylic acid receptors in the Guide to Pharmacology database (GtoPdb). It exists purely as an adjunct to the database to facilitate the recognition of citations to and from the database by citation analyzers. Readers will almost certainly want to visit the relevant sections of the database which are given here under database links.

GtoPdb is an expert-driven guide to pharmacological targets and the substances that act on them. GtoPdb is a reference work which is most usefully represented as an on-line database. As in any publication this work should be appropriately cited, and the papers it cites should also be recognized. This document provides a citation for the relevant parts of the database, and also provides a reference list for the research cited by those parts.

Please note that the database version for the citations given in GtoPdb are to the most recent preceding version in which the family or its subfamilies and targets were substantially changed. The links below are to the current version. If you need to consult the cited version, rather than the most recent version, please contact the GtoPdb curators.

\section{Database links}

Hydroxycarboxylic acid receptors 
http://www.guidetopharmacology.org/GRAC/FamilyDisplayForward?familyld=48

Introduction to Hydroxycarboxylic acid receptors

http://www. guidetopharmacology. org/GRAC/FamilylntroductionForward?familyld=48

Receptors

$\mathrm{HCA}_{1}$ receptor

http://www.guidetopharmacology.org/GRAC/ObjectDisplayForward?objectld=311

$\mathrm{HCA}_{2}$ receptor

http://www.guidetopharmacology.org/GRAC/ObjectDisplayForward?objectld=312

$\mathrm{HCA}_{3}$ receptor

http://www.guidetopharmacology.org/GRAC/ObjectDisplayForward?objectld=313

\section{References}

1. Ahmed K, Tunaru S, Langhans CD, Hanson J, Michalski CW, Kölker S, Jones PM, Okun JG and Offermanns S. (2009) Deorphanization of GPR109B as a receptor for the beta-oxidation intermediate 3OH-octanoic acid and its role in the regulation of lipolysis. J. Biol. Chem. 284: 21928-33 [PMID:19561068]

2. Ahmed K, Tunaru S, Tang C, Müller M, Gille A, Sassmann A, Hanson J and Offermanns S. (2010) An autocrine lactate loop mediates insulin-dependent inhibition of lipolysis through GPR81. Cell Metab. 11: 311-9 [PMID:20374963]

3. Benyó Z, Gille A, Bennett CL, Clausen BE and Offermanns S. (2006) Nicotinic acid-induced flushing is mediated by activation of epidermal langerhans cells. Mol. Pharmacol. 70: 1844-9 [PMID:17008386]

4. Benyó Z, Gille A, Kero J, Csiky M, Suchánková MC, Nüsing RM, Moers A, Pfeffer K and Offermanns S. (2005) GPR109A (PUMA-G/HM74A) mediates nicotinic acid-induced flushing. J. Clin. Invest. 115: 3634-40 [PMID:16322797]

5. Blad CC, van Veldhoven JP, Klopman C, Wolfram DR, Brussee J, Lane JR and ljzerman AP. (2012) Novel 3,6,7-substituted pyrazolopyrimidines as positive allosteric modulators for the hydroxycarboxylic acid receptor 2 (GPR109A). J. Med. Chem. 55: 3563-7 [PMID:22420767]

6. Boatman PD, Lauring B, Schrader TO, Kasem M, Johnson BR, Skinner P, Jung JK, Xu J, Cherrier MC and Webb PJ et al.. (2012) (1aR,5aR)1a,3,5,5a-Tetrahydro-1H-2,3-diaza-cyclopropa[a]pentalene-4-carboxylic acid (MK-1903): a potent GPR109a agonist that lowers free fatty acids in humans. J. Med. Chem. 55: 3644-66 [PMID:22435740]

7. Boatman PD, Schrader TO, Kasem M, Johnson BR, Skinner PJ, Jung JK, Xu J, Cherrier MC, Webb PJ and Semple $G$ et al.. (2010) Potent tricyclic pyrazole tetrazole agonists of the nicotinic acid receptor (GPR109a). Bioorg. Med. Chem. Lett. 20: 2797-800 [PMID:20363624]

8. Cai TQ, Ren N, Jin L, Cheng K, Kash S, Chen R, Wright SD, Taggart AK and Waters MG. (2008) Role of GPR81 in lactate-mediated reduction of adipose lipolysis. Biochem. Biophys. Res. Commun. 377: 987-91 [PMID:18952058]

9. Carballo-Jane E, Gerckens LS, Luell S, Parlapiano AS, Wolff M, Colletti SL, Tata JR, Taggart AK, Waters MG and Richman JG et al.. (2007) Comparison of rat and dog models of vasodilatation and lipolysis for the calculation of a therapeutic index for GPR109A agonists. J Pharmacol Toxicol Methods 56: 308-16 [PMID:17643322]

10. Davenport AP, Alexander SP, Sharman JL, Pawson AJ, Benson HE, Monaghan AE, Liew WC, Mpamhanga CP, Bonner TI and Neubig RR et al.. (2013) International Union of Basic and Clinical Pharmacology. LXXXVIII. G protein-coupled receptor list: recommendations for new pairings with cognate ligands. Pharmacol. Rev. 65: 967-86 [PMID:23686350]

11. DiGirolamo M, Newby FD and Lovejoy J. (1992) Lactate production in adipose tissue: a regulated function with extra-adipose implications. FASEB J. 6: 2405-12 [PMID:1563593]

12. Feingold KR, Moser A, Shigenaga JK and Grunfeld C. (2011) Inflammation inhibits GPR81 expression in adipose tissue. Inflamm. Res. 60: 991-5 [PMID:21751047]

13. Hagström-Toft E, Enoksson S, Moberg E, Bolinder J and Arner P. (1997) Absolute concentrations of 
glycerol and lactate in human skeletal muscle, adipose tissue, and blood. Am. J. Physiol. 273: E584-92 [PMID:9316449]

14. Hanson J, Gille A, Zwykiel S, Lukasova M, Clausen BE, Ahmed K, Tunaru S, Wirth A and Offermanns S. (2010) Nicotinic acid- and monomethyl fumarate-induced flushing involves GPR109A expressed by keratinocytes and COX-2-dependent prostanoid formation in mice. J. Clin. Invest. 120: 2910-9 [PMID:20664170]

15. HUCKABEE WE. (1958) Relationships of pyruvate and lactate during anaerobic metabolism. I. Effects of infusion of pyruvate or glucose and of hyperventilation. J. Clin. Invest. 37: 244-54 [PMID:13513755]

16. Imbriglio JE, Chang S, Liang R, Raghavan S, Schmidt D, Smenton A, Tria S, Schrader TO, Jung JK and Esser C et al.. (2010) GPR109a agonists. Part 2: pyrazole-acids as agonists of the human orphan Gprotein coupled receptor GPR109a. Bioorg. Med. Chem. Lett. 20: 4472-4 [PMID:20615702]

17. Imbriglio JE, DiRocco D, Bodner R, Raghavan S, Chen W, Marley D, Esser C, Holt TG, Wolff MS and Taggart AK et al.. (2011) The discovery of high affinity agonists of GPR109a with reduced serum shift and improved ADME properties. Bioorg. Med. Chem. Lett. 21: 2721-4 [PMID:21185185]

18. Irukayama-Tomobe $\mathrm{Y}$, Tanaka H, Yokomizo T, Hashidate-Yoshida T, Yanagisawa M and Sakurai T. (2009) Aromatic D-amino acids act as chemoattractant factors for human leukocytes through a $G$ proteincoupled receptor, GPR109B. Proc. Natl. Acad. Sci. U.S.A. 106: 3930-4 [PMID:19237584]

19. Jeninga EH, Bugge A, Nielsen R, Kersten S, Hamers N, Dani C, Wabitsch M, Berger R, Stunnenberg HG and Mandrup S et al.. (2009) Peroxisome proliferator-activated receptor gamma regulates expression of the anti-lipolytic G-protein-coupled receptor 81 (GPR81/Gpr81). J. Biol. Chem. 284: 26385-93 [PMID:19633298]

20. Jung JK, Johnson BR, Duong T, Decaire M, Uy J, Gharbaoui T, Boatman PD, Sage CR, Chen R and Richman JG et al.. (2007) Analogues of acifran: agonists of the high and low affinity niacin receptors, GPR109a and GPR109b. J. Med. Chem. 50: 1445-8 [PMID:17358052]

21. Knowles HJ, te Poele RH, Te Poole R, Workman P and Harris AL. (2006) Niacin induces PPARgamma expression and transcriptional activation in macrophages via HM74 and HM74a-mediated induction of prostaglandin synthesis pathways. Biochem. Pharmacol. 71: 646-56 [PMID:16386710]

22. Kreisberg RA. (1980) Lactate homeostasis and lactic acidosis.Ann. Intern. Med. 92: 227-37 [PMID:6766289]

23. Lee DK, Nguyen T, Lynch KR, Cheng R, Vanti WB, Arkhitko O, Lewis T, Evans JF, George SR and O'Dowd BF. (2001) Discovery and mapping of ten novel G protein-coupled receptor genes. Gene 275: 8391 [PMID:11574155]

24. Liu C, Kuei C, Zhu J, Yu J, Zhang L, Shih A, Mirzadegan T, Shelton J, Sutton S and Connelly MAt al.. (2012) 3,5-Dihydroxybenzoic acid, a specific agonist for hydroxycarboxylic acid 1, inhibits lipolysis in adipocytes. J. Pharmacol. Exp. Ther. 341: 794-801 [PMID:22434674]

25. Liu C, Wu J, Zhu J, Kuei C, Yu J, Shelton J, Sutton SW, Li X, Yun SJ and Mirzadegan モt al.. (2009) Lactate inhibits lipolysis in fat cells through activation of an orphan G-protein-coupled receptor, GPR81. J. Biol. Chem. 284: 2811-22 [PMID:19047060]

26. Lukasova M, Malaval C, Gille A, Kero J and Offermanns S. (2011) Nicotinic acid inhibits progression of atherosclerosis in mice through its receptor GPR109A expressed by immune cells. J. Clin. Invest. 121: 1163-73 [PMID:21317532]

27. Maciejewski-Lenoir D, Richman JG, Hakak Y, Gaidarov I, Behan DP and Connolly DT. (2006) Langerhans cells release prostaglandin D2 in response to nicotinic acid. J. Invest. Dermatol. 126: 2637-46 [PMID:17008871]

28. Mahboubi K, Witman-Jones T, Adamus JE, Letsinger JT, Whitehouse D, Moorman AR, Sawicki D, Bergenhem N and Ross SA. (2006) Triglyceride modulation by acifran analogs: activity towards the niacin high and low affinity G protein-coupled receptors HM74A and HM74. Biochem. Biophys. Res. Commun. 340: 482-90 [PMID:16389067]

29. Marbach EP and Weil MH. (1967) Rapid enzymatic measurement of blood lactate and pyruvate. Use and significance of metaphosphoric acid as a common precipitant. Clin. Chem. 13: 314-25 [PMID:6036716] 
30. Martin PM, Ananth S, Cresci G, Roon P, Smith S and Ganapathy V. (2009) Expression and localization of GPR109A (PUMA-G/HM74A) mRNA and protein in mammalian retinal pigment epithelium. Mol. Vis. 15: 362-72 [PMID:19223991]

31. Niessner H and Beutler E. (1973) Fluorometric analysts of glycolytic intermediates in human red blood cells. Biochem Med 8: 123-34 [PMID:4744313]

32. Offermanns S, Colletti SL, Lovenberg TW, Semple G, Wise A and IJzerman AP. (2011) International Union of Basic and Clinical Pharmacology. LXXXII: Nomenclature and Classification of Hydroxy-carboxylic Acid Receptors (GPR81, GPR109A, and GPR109B). Pharmacol. Rev. 63: 269-90 [PMID:21454438]

33. Osnes JB and Hermansen L. (1972) Acid-base balance after maximal exercise of short duration.J Appl Physiol 32: 59-63 [PMID:5007019]

34. Palani A, Rao AU, Chen X, Huang X, Su J, Tang H, Huang Y, Qin J, Xiao D and Degrado \&t al.. (2012) Discovery of SCH 900271, a Potent Nicotinic Acid Receptor Agonist for the Treatment of Dyslipidemia. ACS Med Chem Lett 3: 63-8 [PMID:24900372]

35. Ren N, Kaplan R, Hernandez M, Cheng K, Jin L, Taggart AK, Zhu AY, Gan X, Wright SD and Cai TQ. (2009) Phenolic acids suppress adipocyte lipolysis via activation of the nicotinic acid receptor GPR109A (HM74a/PUMA-G). J. Lipid Res. 50: 908-14 [PMID:19136666]

36. Richman JG, Kanemitsu-Parks M, Gaidarov I, Cameron JS, Griffin P, Zheng H, Guerra NC, Cham L, Maciejewski-Lenoir D and Behan DP et al.. (2007) Nicotinic acid receptor agonists differentially activate downstream effectors. J. Biol. Chem. 282: 18028-36 [PMID:17452318]

37. Sakurai T, Davenport R, Stafford S, Grosse J, Ogawa K, Cameron J, Parton L, Sykes A, Mack S and Bousba $S$ et al.. (2014) Identification of a novel GPR81-selective agonist that suppresses lipolysis in mice without cutaneous flushing. Eur. J. Pharmacol. 727: 1-7 [PMID:24486398]

38. Schaub A, Fütterer A and Pfeffer K. (2001) PUMA-G, an IFN-gamma-inducible gene in macrophages is a novel member of the seven transmembrane spanning receptor superfamily. Eur. J. Immunol. 31: 3714-25 [PMID:11745392]

39. Semple G, Skinner PJ, Cherrier MC, Webb PJ, Sage CR, Tamura SY, Chen R, Richman JG and Connolly DT. (2006) 1-Alkyl-benzotriazole-5-carboxylic acids are highly selective agonists of the human orphan Gprotein-coupled receptor GPR109b. J. Med. Chem. 49: 1227-30 [PMID:16480258]

40. Semple G, Skinner PJ, Gharbaoui T, Shin YJ, Jung JK, Cherrier MC, Webb PJ, Tamura SY, Boatman PD and Sage CR et al.. (2008) 3-(1H-tetrazol-5-yl)-1,4,5,6-tetrahydro-cyclopentapyrazole (MK-0354): a partial agonist of the nicotinic acid receptor, G-protein coupled receptor 109a, with antilipolytic but no vasodilatory activity in mice. J. Med. Chem. 51: 5101-8 [PMID:18665582]

41. Shen HC, Ding FX, Deng Q, Wilsie LC, Krsmanovic ML, Taggart AK, Carballo-Jane E, Ren N, Cai TQ and Wu TJ et al.. (2009) Discovery of novel tricyclic full agonists for the G-protein-coupled niacin receptor 109A with minimized flushing in rats. J. Med. Chem. 52: 2587-602 [PMID:19309152]

42. Shen HC, Ding FX, Raghavan S, Deng Q, Luell S, Forrest MJ, Carballo-Jane E, Wilsie LC, Krsmanovic ML and Taggart AK et al.. (2010) Discovery of a biaryl cyclohexene carboxylic acid (MK-6892): a potent and selective high affinity niacin receptor full agonist with reduced flushing profiles in animals as a preclinical candidate. J. Med. Chem. 53: 2666-70 [PMID:20184326]

43. Shen HC, Szymonifka MJ, Kharbanda D, Deng Q, Carballo-Jane E, Wu KK, Wu TJ, Cheng K, Ren N and Cai TQ et al.. (2007) Discovery of orally bioavailable and novel urea agonists of the high affinity niacin receptor GPR109A. Bioorg. Med. Chem. Lett. 17: 6723-8 [PMID:18029181]

44. Shen HC, Taggart AK, Wilsie LC, Waters MG, Hammond ML, Tata JR and Colletti SL. (2008) Discovery of pyrazolopyrimidines as the first class of allosteric agonists for the high affinity nicotinic acid receptor GPR109A. Bioorg. Med. Chem. Lett. 18: 4948-51 [PMID:18752940]

45. Skinner PJ, Cherrier MC, Webb PJ, Sage CR, Dang HT, Pride CC, Chen R, Tamura SY, Richman JG and Connolly DT et al.. (2007) 3-Nitro-4-amino benzoic acids and 6-amino nicotinic acids are highly selective agonists of GPR109b. Bioorg. Med. Chem. Lett. 17: 6619-22 [PMID:17931863]

46. Skinner PJ, Webb PJ, Sage CR, Dang TH, Pride CC, Chen R, Tamura SY, Richman JG, Connolly DT and Semple G. (2009) 5-N,N-Disubstituted 5-aminopyrazole-3-carboxylic acids are highly potent agonists of 
GPR109b. Bioorg. Med. Chem. Lett. 19: 4207-9 [PMID:19524438]

47. Soga T, Kamohara M, Takasaki J, Matsumoto S, Saito T, Ohishi T, Hiyama H, Matsuo A, Matsushime H and Furuichi K. (2003) Molecular identification of nicotinic acid receptor. Biochem. Biophys. Res.

Commun. 303: 364-9 [PMID:12646212]

48. Southern C, Cook JM, Neetoo-Isseljee Z, Taylor DL, Kettleborough CA, Merritt A, Bassoni DL, Raab WJ, Quinn E and Wehrman TS et al.. (2013) Screening $\beta$-Arrestin Recruitment for the Identification of Natural Ligands for Orphan G-Protein-Coupled Receptors. J Biomol Screen 18: 599-609 [PMID:23396314]

49. Sprecher D, Maxwell M, Goodman J, White B, Tang CM, Boullay V and de Gouville AC. (2015) Discovery and characterization of GSK256073, a non-flushing hydroxy-carboxylic acid receptor 2 (HCA2) agonist. Eur. J. Pharmacol. 756: 1-7 [PMID:25773497]

50. Taggart AK, Kero J, Gan X, Cai TQ, Cheng K, Ippolito M, Ren N, Kaplan R, Wu K and Wu TJet al.. (2005) (D)-beta-Hydroxybutyrate inhibits adipocyte lipolysis via the nicotinic acid receptor PUMA-G. J. Biol. Chem. 280: 26649-52 [PMID:15929991]

51. Tang H, Lu JY, Zheng X, Yang Y and Reagan JD. (2008) The psoriasis drug monomethylfumarate is a potent nicotinic acid receptor agonist. Biochem. Biophys. Res. Commun. 375: 562-5 [PMID:18722346]

52. Tang Y, Zhou L, Gunnet JW, Wines PG, Cryan EV and Demarest KT. (2006) Enhancement of arachidonic acid signaling pathway by nicotinic acid receptor HM74A. Biochem. Biophys. Res. Commun. 345: 29-37 [PMID:16674924]

53. Thangaraju M, Cresci GA, Liu K, Ananth S, Gnanaprakasam JP, Browning DD, Mellinger JD, Smith SB, Digby GJ and Lambert NA et al.. (2009) GPR109A is a G-protein-coupled receptor for the bacterial fermentation product butyrate and functions as a tumor suppressor in colon. Cancer Res. 69: 2826-32 [PMID:19276343]

54. Tunaru S, Kero J, Schaub A, Wufka C, Blaukat A, Pfeffer K and Offermanns S. (2003) PUMA-G and HM74 are receptors for nicotinic acid and mediate its anti-lipolytic effect. Nat. Med. 9: 352-5 [PMID:12563315]

55. van Herk T, Brussee J, van den Nieuwendijk AM, van der Klein PA, IJzerman AP, Stannek C, Burmeister A and Lorenzen A. (2003) Pyrazole derivatives as partial agonists for the nicotinic acid receptor. J. Med. Chem. 46: 3945-51 [PMID:12930155]

56. van Veldhoven JP, Blad CC, Artsen CM, Klopman C, Wolfram DR, Abdelkadir MJ, Lane JR, Brussee J and ljzerman AP. (2011) Structure-activity relationships of trans-substituted-propenoic acid derivatives on the nicotinic acid receptor HCA2 (GPR109A). Bioorg. Med. Chem. Lett. 21: 2736-9 [PMID:21167710]

57. Wise A, Foord SM, Fraser NJ, Barnes AA, Elshourbagy N, Eilert M, Ignar DM, Murdock PR, Steplewski K and Green A et al.. (2003) Molecular identification of high and low affinity receptors for nicotinic acid.J. Biol. Chem. 278: 9869-74 [PMID:12522134]

58. Wu FM, Huang HG, Hu M, Gao Y and Liu YX. (2006) [Molecular cloning, tissue distribution and expression in engineered cells of human orphan receptor GPR81]. Sheng Wu Gong Cheng Xue Bao22: 408-12 [PMID:16755919]

59. Zhang Y, Schmidt RJ, Foxworthy P, Emkey R, Oler JK, Large TH, Wang H, Su EW, Mosior MK and Eacho $\mathrm{PI}$ et al.. (2005) Niacin mediates lipolysis in adipose tissue through its G-protein coupled receptor HM74A. Biochem. Biophys. Res. Commun. 334: 729-32 [PMID:16018973] 